\title{
THE THEOLOGICAL SIGNIFICANCE OF THE DISCOVERY OF AMERICA $(*)\left({ }^{\star \star}\right)$.
}

\author{
LEWIS HANKE \\ University of Massachusetts. Amherst.
}

In reading the historical literature on the Renaissance and the Reformation, one gets the impression that Spain and Portugal had relatively little to offer, and that theology particularly was a learned enterprise that flourished only in certain soils, particularly those near Rome. American experience and American problems received almost no attention at the Council of Trent (1545-1563), that great ecumenical gathering of bishops which was probably the most thoroughgoing reform in the history of the Roman Catholic Church. The Council was principally concerned to launch a theological attack on the Protestants, and the powerful Jesuits had not yet developed much interest in New World problems.

However we may explain the fact that most European thinkers in the sixteenth century paid little or no attention to the Iberian scholastic renaissance, for three centuries thereafter this neglect of American developments continued. Standard histories of philosophy, theology, and general church history rarely made any reference to America or to the disputes which its discovery provoked among Spaniards of the conquest period. Even such a generally conscientious and competent scholar as the nineteenth-century historian of the papacy, Ludwig von Pastor, included little on America in his massive opus, and not until

(*). - Este artigo será apresentado como Comunicação na International Conference on First Images of America: The Impact of the New World on the Old, sob os auspícios do Center for Medieval and Renaissance Studies da Universidade da Califórnia, Los Angeles e da The Renaissance Society of America. Essa reunião terá lugar a 7 de fevereiro de 1975 em Los Angeles. (Nota da Redação).

$(* *)$. - I wish to acknowledge with thanks the suggestions and questions of Dr. Stafford Poole, C. M., my colleague in Las Casas studies. Specific quotations are to his "Comments and Reflections" on an earlier verion of my paper. 
Robert Streit, S. J., began in 1916 to publish his monumental Bibliotheca Missionum did the scholarly world have any solid bibliographical and documentary basis for the study of the history of the Roman Catholic Church in America (1). For this and other reasons, during the last generation the world of American and European scholarship has become more generally aware of the doctrines and disputes of the Dominican Bartolomé de Las Casas and other Spanish theologians who concerned themselves with the ecclesiastical problems raised during the years between 1492 and the Council of Trent (2). But even now much remains to be learned in this field, though what has been learned is not always recognized. The most detailed study on the salvation of pagans, by the Spanish Jesuit Ángel Santos Hernández, for example, devotes almost no attention to America, although substantial contributions on the subject have been published in Spanish and in other languages ( 3 ).

Throughout medieval times Christian theologians debated whether pagans could be saved. The Catalan Raymond Lull declared in the thirteenth century:

(1). - The first three volumes are particularly valuable.

(2). - For a recent work embodying much research, see the volume edited by Juan Friede and Benjamin Keen, Bartolomé de Las Casas in History. Toward an Understanding of the Man and His Work (DeKalb: Northern Illinois University Press, 1974).

(3). - Ángel Santos Hernández, Salvación y paganismo. El problema teológico de la salvación de los infieles (Santander, 1960).

For a general survey, see Venancio D. Carro, O. P., La teología y los teólogos - juristas españoles ante la conquista de América 2nd ed. (Salamanca, 1951). An unusual item is in the Catholic Dictionary of Theology, I (London, 1962), pp. 69-70, entitled "America, theological significance of". This article is an imaginative and path-breaking statement in some ways, but to indicate how isolated the editors are bibliographically, they do not cite any of the numerous Spanish publications on the subject, and even ignore writings in English. Their bibliographical note includes largely works in French, and their article does not refer to any of the principal events and ideas in my paper.

Controversy among theologians on these issues still continues as may be seen from Francis S. Shea, "The Principles of Extra-Sacramental Justification in Relation to 'Extra Ecclesiasm Nulla Salus'", Proceedings of the Catholic Theological Society of America, X (1955), pp. 125-151. See also Riccardo Lombardi, S. J., The Salvation of the Unbeliever (Westminster, Md., 1956). Trans. from the Italian by Dorothy M. White. As Dr. Poole comments: "the problem of salvation of the non-Christian is still one that has not been adequately solved by theologians. The principle of Deus non denegat gratiam is in conflict with the principle that the Church and the gospel are necessary for salvation. For theologians to admit all men too readily to salvation is to weaken the need for the Church; to lay too heavy an emphasis on the necessity of the Church is to reject common sense and deny the will of God to save all men. It should also be noted that the emphasis on the necessity of the Church tends to increase missionary zeal and labor". 
"God hath such love for His people that almost all men in the world shall be saved; since, if more were damned than saved, Christ's mercy would be without great love".

This assertion, however, was solemnly condemned as heretical by Pope Gregory XI, and the question whether force should be used to promote conversion to Christianity also produced deep disagreements (4). The Order of Crucifers claimed in the early fifteenth century to be authorized by papal and imperial privileges to conquer by force of arms the lands of pagans on Poland's frontiers, a position which was strongly opposed by Paul Wladimiri, Rector of Cracow University, at the time of the Council of Constance (1414-1418) (5). Theologians paid considerable attention to what they called "God's virtuous heathen", but they achieved no consensus in the centuries preceding Columbus (6). Many believed that only a few could be saved, but Thomas Aquinas had a more generous position than that of the Augustinians for example, for he held that God would employ extraordinary means to bring the conscientious pagan into the Christian fold, according to the axiom of the scholastics, Facienti quod in se est, Deus non denegat gratiam:

"God does not refuse grace to one who does his best".

But this was a theoretical attitude, rarely put to the test of reality, for few Europeans actually saw or had meaningful relations with many heathens whether virtuous or not, inasmuch as their missionary activities had taken place largely on the periphery of the medieval world. Thus the first time Christians confronted millions of infidels and were faced with the many practical and theoretical problems of converting them was when America was discovered. One student has explained in this way the inability of the medieval thinkers to cope with American problems: p. 14 .

(4). - As cited by G. G. Coulton, The Inquisition (London, 1929),

(5). - The Works of Paul Wladimiri (A Selection), I (Warsaw, 1968). Lic. Enrique Ruiz Maldonado, O. P., of Mexico City, was kind enough to bring this substantial contribution to my atention.

(6). - For a recent contribution, see the dissertation by Thomas George Hahn, "God's Friends: Virtuous Heathen in Later Medieval Thought and English Literature" (University of California, Los Angeles, 1974). A specialized study is Heiko A. Oberman, " "Facientibus Quod In Se Est Deus Non Denegat Gratiam'. Robert Holcot, O. P., and the Beginnings of Luther's Theology", Harvard Theological Review, LV (1962), pp. 317-342. 


\begin{abstract}
"Medieval philosophers, including the Thomists, were generally under the influence of Aristotelian and Ptolemaic natural science and geography. Hence from a philosophical and theological point of view they were unequipped at first to deal with the new and astonishing problem of a New World. A fairly good parallel would be if, in our age, we should suddenly discover that intelligent life exists on a nearby planet. The theologians would be running all over the place trying to explain, and we would probably end up discussing many of the same questions that the Spaniards of the sixteenth century did" (7).
\end{abstract}

Spaniards were not only in the forefront of all those who explored the vast reaches of the New World - Marcel Bataillon has pointed out that they roamed over as much territory in the seventy years after 1492 as had been explored in the previous one-thousand years by other Europeans - but they were pioneers too in tackling the theoretical and theological issues involved. Spanish efforts to Christianize the Indians have been characterized as a "spiritual conquest" by Robert Ricard, of no less significance than the astounding military conquests of Hernando Cortez, Francisco Pizarro, and the other bold conquistadores who carried the banners of Spain to the far corners of her empire in America (8).

Europeans did not entirely ignore American developments, despite their preoccupation with the Turkish peril and the Protestant revolt. One of the first attempts to understand the implication for Christians of the existence of masses of Indians in the New World who had had no previous contact with Christianity was made by Bartolomé Sybilla in his Speculum peregrinarum quaestionum (1516). Then Emperor Maximilian (1459-1519) became interested in the souls of the Indians and requested an opinion from Juan de Heindenburg, better known as Trithemio, who replied in his Curiositas Regia (1521) that 1933).

(8). - Robert Ricard, La "Conquête Spirituelle" du Mexique (Paris,

(7). - The last quotation is from Dr. Poole's "Comments and Reflections". The other material is based on material in Santos Hernández, Salvación $y$ paganismo, pp. 80-81. The Protestant movement was far different. As George Huntston Williams stated: "In the Age of Discovery and Reformation the initial forces of Christian renewal were by and large the forces which tended to restrict rather than enlarge the scope of Christ's salvation of the world", "Sectarian Ecumenicity: Reflections on a Little Noticed Aspect of the Radical Reformation", Review and Expositor, LXIV (1967), pp. 41-160. See also by the same author, "Erasmus and the Reformers on Non-Christian Religions and Salus Extra Ecclesiam", in Theodore K. Rabb and Jerrold E. Seigel, eds., Action and Conviction in Early Modern Europe: Essays in Memory of E. H. Harbison (Princeton, 1969), pp. 319-370. "There was little concern for the salvation of peoples beyond the hearing of missionaries" (p. 370). 


\begin{abstract}
"those infidels who had led innocent lives would suffer no positive punishment whatsoever, though they would be excluded from supernatural felicity or divine vision".
\end{abstract}

Here Trithemio was applying the concept of limbo, which medieval theologians had developed to explain what happened to the patriarchs of the Old Testament prior to the coming of Christ and also to explain what happened to infants who died without baptism. About the same time as Trithemio, the Archibishop of Turin, Claude Seyssel, elaborated the doctrine that ordinary pagans would be consigned to limbo, the intermediate stage between heaven and hell. None of the Spanish thinkers who wrestled with the theological problems created by the discovery of America seems to have followed the example of Trithemio and Seyssel in trying to apply the medieval limbo idea to the American Indians; indeed, the concept of limbo has never been and is not now a teaching of the Church.

There seems to have been no sustained interest in Rome during the early years concerning America and the Indians. As John W. O'Malley makes clear in the most recent and most meticulous examination of the sources, there was almost no interest manifested in Rome:

\footnotetext{
"Although representatives of the missions in the New World were present at the Fifth Lateran Council which met in Rome from 1512 to 1517 , there is not a single mention of that World in the acts and orations from the Council which have survived" (9).
}

Individual authorities, however, such as Cajetan (Tommaso de Vio), Cardinal and former master general of the Dominican order, showed good sense and concern when he replied in 1532-1533 to various pastoral questions sent him by Dominican missionaries in America (10). Cajetan had earlier argued strongly that conversions could not be forced and could be effected only by good preaching and good instruction by holy missionaries. He naturally denounced as unjust and immoral the wars of conquest in America (11).

Early in the history of America a new element entered into the problem - the idea that all Spaniards, laymen and priests alike, had an obligation to Christianize the Indians. During the long centuries of

(9). - John W. O'Malley, "The Discovery of America in the Context of Reform Thought at the Papal Court in the Early Cinquecento", p. 5.

(10) . - V. M. Pollet, "De Caietani scripto: "Ad septemdecim quaesita respousiones' ", Angelicum, 14 (1937), pp. 538-559.

(11). - O'Malley, "The Discovery of America", p. 17. 
the Reconquista, when Spain was slowly recovering her lands from the Moslems, there had developed no doctrine that the Spanish people had an obligation to help convert the Jews or Moslems. There was little effort by anyone in Spain to Christianize the Moslems, though there were concerted attempts to convert Jews, especially by St. Vincent Ferrer. One of the methods used was compulsory attendance at sermons, but there seems to have been little or no theological doctrine back of these attempts, and certainly there was no feeling that lay Spaniards had a special responsibility to bring Jews or anyone else into the Christian fold. As Harold B. Johnson, Jr., has stated in a thoughtful analysis of missionary efforts in medieval Spain, even the crown

"had not been especially eager to convert Jews and Moors until the late fifteenth century, and then only for reasons of Castilian internal politics" (12).

Only with the opening up of the New World with its millions of pagans did there come to be expressed the idea that all Spaniards should look upon the Indians as potential brothers and attempt to Christianize them. The Spaniards who enjoyed tribute and labor from Indians were expressly charged with aiding their conversion, a commitment never imposed on the encomenderos in medieval Spain (13). Most important of all, the Spanish Crown regarded the conversion of the Indians as the principal reason for establishing the "justness" of Spanish rule.

The missionaries, of course, were fired with a burning zeal to convert the Indians, and many of the hundreds of missionaries who hurried to America were determined to re-establish in the New World the foundations of Christendom which had been so severely shaken in Europe by the Protestant revolt. Their harvest was impressive. As Alonso de Zorita pointed out in an eloquent statement to the Council of the Indies in 1584, Spaniards made very little headway in converting the Moors in Granada during a seventy-year period. But in America missionaries had achieved much:

"usually the missionaries had taught the Indians to read, write, and observe good customs. Many had been taught how to

(12). - See Dr. Johnson's comments in Lewis Hanke, All Mankind is One (DeKalb: Northern Illinois University Press, 1974), pp. 167-170.

(13). - Robert S. Chamberlain, "Castilian Backgrounds of the repartimiento-encomienda", Carnegie Institution of Washington. Contributions to American Anthropology and History, 5 (Washington, D. C., 1939), pp. 19-66. 
play musical instruments so that they could play in church, while others had been taught grammar and rhetoric. Some have become excellent Latinists and have composed very elegant orations and poetry" (14).

In comparing Spain and America, Zorita found that there had been a tremendous missionary effort overseas and far superior to the conversion attempts in Granada.

But the success in America had not been accomplished easily, because from the earliest years of the conquest there had been sharp differences of opinion, among lay and religious figures alike, on the capacity of the New World natives for Christianity and European civilization. The archives of the Council of the Indies began to be filled with divergent testimony on the nature of the Indians from the time it was established in 1524, and occasionally Europeans who stayed at home had an opportunity to see a few Indians or their handiwork. Thus Albrecht Dürer in 1520 marvelled at the artistic ability shown by the Indian jewelry and featherwork sent by Cortez to Charles V for exhibition in Brussels. And when Cortez was engaged in getting several of his natural children legitimized he sent to Rome a group of Aztec jugglers to assist in obtaining papal approval (15). Charles V also once spent a pleasant afternoon in Valladolid watching Indian dancers and listening to their exotic music (16). But the first time that theological and ideological questions originating in America were reflected in a publication in Europe occurred in 1537, when the Latin letter sent by the Dominican Julián Garcés, the Bishop of Tlaxcala in Mexico, was printed in Rome. This rare item, whose only known copy is in the John Carter Brown Library in an excellently preserved exemplar, was a part of the campaign being waged to convince Pope Paul III that the Indians could and should be Christianized, and their bodies and property protected from rapacious conquistadores (17).

(14). - Letter by Alonso de Zorita to the Council of the Indies, March 10, 1584. Archivo General de Indias (Sevilla), Patronato 231, No. 7, ramo 7. The letter has been printed by Manuel Serrano y Sanz in his edition of Zorita's Historia de la Nueva España (Madrid, 1909), pp. 502-524, where it is entitled "Parecer del Doctor Alonso de Zurita sobre la enseñanza espiritual de los indios".

(15). - Howard F. Cline, "Hernán Cortés and the Aztec Indians in Spain", Quarterly Journal of the Library of Congress, XXVI (April, 1969), No. 2, pp. 70-90.

(16). - Diego Valadés, Rhetorica Christiana (Perouse, 1579).

(17) . - For bibliography on the Garcés letter and the bull Sublimis Deus of Pope Paul III, see Robert Streit, Bibliotheca Missionum, II. For a detailed treatment of the subject, see Lewis Hanke, "Pope Paul III and the American Indians", Harvard Theological Review, XXX (Cambridge, Mass., 1937), pp. 65-102. 
The Council of the Indies, which considered that it had the principal authority and responsibility in the matter, had sought advice in many quarters, and a flood of sharply contradictory opinions resulted. One Dominican, Domingo de Betanzos, submitted such an unfavorable response that other ecclesiastics concluded that he considered Indians incapable of Christianity. Therefore they carried the dispute not only to the Council of the Indies but to Rome itself where in 1537 Pope Paul III was prevailed upon to issue the famous bull Sublimis Deus which declared Indians "truly men" and capable of the faith in notable words. The first two paragraphs read as follows:

"The sublime God so loved the human race that $\mathrm{He}$ created man in such wise that he might participtae, not only in the good that other creatures enjoy, but endowed him with capacity to attain to the inaccessible and invisible Supreme Good and behold it face to face, and since man, according to the testimony of the sacred scriptures, has been created to enjoy eternal life and happiness, which none may obtain save through faith in our Lord Jesus Christ, it is necessary that he should possess the nature and faculties enabling him to receive that faith; and that whoever is thus endowed should be capable of receiving that same faith. Nor is it credible that any one should possess so little understanding as to desire the faith and yet be destitute of the most necessary faculty to enable him to receive it. Hence Christ, who is the Truth itself, that has never failed and can never fail, said to the preachers of the faith whom $\mathrm{He}$ chose for that office "Go ye and teach all nations". He said all, without exception, for all are capable of receiving the doctrines of the faith.

The enemy of the human race, who opposes all good deeds in order to bring men to destruction, beholding and envying this, invented a means never before heard of, by which he might hinder the preaching of God's word of Salvation to the people; he inspired his satellites who, to please him, have not hesitated to publish abroad that the Indians of the West and the South, and other people of whom We have recent knowledge should be treated as dumb brutes created for our service, pretending that they are incapable of receiving the catholic faith" (18).

By this time Las Casas had entred the fight on behalf of the Indians, after a long period of silence in the Dominican convent on the island of Hispaniola. He emphasized the need to educate the Indians and to persuade them of the truth of Christian doctrine. He

(18). - Ibid., p. 71-72. 
entered into conflict with those missionaries - especially Franciscans - who favored rapid and wholesale bantism of the natives, without too many questions asked or catechisms learned. So hot did this argument become in America that it was referred to Spain, where the Emperor Charles V called upon a distinguished committee of theologians at the University of Salamanca, headed by the Dominican Francisco de Vitoria, which in 1541 decided in favor of those who insisted on proper instruction. It is not surprising that the Dominicans of Salamanca should support the position of those who insisted on proper doctrinal instruction for the Indians, inasmuch as many of their old competitors the Franciscans favored the position of little instruction. Yet there were larger issues involved, too, as quickly becomes clear in studying the battle over education for Indians.

Could the Indians really be educated? The Franciscan school for Indians at Tlatelolco in Mexico was being opposed, particularly if the objective was to get them ready to be ordained for the priesthood. Betanzos was among those who opposed. As was usually the case, the dispute was carried back to Spain for further discussion, and we find one prominent Franciscan, Alfonso de Castro, who wrote a treatise in 1542 entitled Whether the Natives of the New World Should be Instructed in the Mysteries of Theology and the Liberal Arts (19).

Castro was a distinguished scholar who taught for thirty years in the Franciscan convent in Salamanca and had become famous for his treatise against Protestantism, Adversus Omnes Haereses (Paris, 1534). With Francisco de Vitoria, he was considered one of the outstanding theologians of the time. His 1542 opinion in favor of instruction for the Indians is of value in understanding the arguments against teaching them, which were:

1. - The Indians are inconstant in the Christian faith;

2. - They live obscene lives; because the Indians are like swine, Christians should not throw pearls before them;

3. - The sacred texts of the Bible should not be shown to the people.

On the last point, Castro argued that the

"mysteries of the Christian faith have value in themselves"

(19) . - For the text of this and valuable comments, see Juan B. Olaechea Labayen, "Opinión de los teólogos españoles de dar estudios mayores a indios", Anuario de Estudios Americanos, XV (Sevilla, 1958), pp. 113-200. 
and thus the Bible should not be hidden from the people. In this Castro's doctrine coincided with that of Bishop Juan de Zumárraga of Mexico, who in his Conclusion exhortatoria favored the translation of the Bible into the popular languages so that it might be read by everyone:

"I do not understand why our doctrine should be hidden away from all but those few called theologians. No one can be called a Platonist unless he has read Plato. Likewise, no one may be called a Christian who has not read the doctrine of Jesus Christ".

Castro's argument that the scriptures should be made widely available to the people must have surprised some of his contemporaries and perhaps explains why he buttressed his own views with the written support of five other established theologians, including the already famous Dominican Francisco de Vitoria. These theologians not only approved Castro's doctrine, they also explained in detail why they did so. They had never been to the New World, and they may never have seen one of the Indians brought to Spain by missionaries or conquistadores. But they perceived the deep issues involved in Castro's treatise, and their formal opinions, as drawn up at the time Castro presented his treatise to Charles V, are a notable part of the documentation available on the theological aspects of early American history. Vitoria had this to say:

"Everything that has been said by the Reverend Father Fray Alfonso de Castro seems to me to have been said in a way that is learned, pious, and religious. I am all the more amazed that anyone should have been the author or inventor of such dangerous (or better, deadly) advice for keeping those barbarians from learning and instruction, both human and divine. Certainly not even the devil could have thought up a more effective means than this for instilling in those peoples a perpetual hatred for the Christian religion. Many have abandoned Christ the Lord and the apostles after they had received the faith in different places. But it has not been thought for that reason that Christian doctrine should not be taught to others or that anyone should be kept from instruction".

Four other theologians also approved Castro's doctrine, including Luis de Carvajal who stated: 
"I think that care should be taken that the peoples of the Indies be instructed with the liberal arts and the knowledge of Sacred Scripture. For who are we that we should show the partiality that Christ himself did not have? On the contrary, if these new peoples should see that they are carefully kept from our mysteries, we would give them the opportunity to form a most deadly suspicion. Further, it is ridiculous to admit them to baptism, to the Eucharist, and to the absolution and forgiveness of sins, but not to the knowledge of Scripture. Now it is indeed true that when the unworthy are admitted to a participation in the sacraments that which is holy is thrown to dogs. But whoever are by right admitted to these are for that reason worthy to share in the mysteries".

But the opponents of Indian education triumphed. Betanzos and the Dominican provincial Diego de la Cruz sent the Emperor Charles $\mathrm{V}$ a letter in the year after Castro's treatise, in which they declared strongly against Indian education:

"Indians should not study because no benefit may be expected from their education, first because they will not be able to preach for a long time inasmuch as this requires an authority over the people which they do not have; moreover, those who do study are worse than those who do not.

In the second place, Indians are not stable persons to whom one should entrust the preaching of the Gospel. Finally, they do not have the ability to understand correctly and fully the Christian faith, nor is their language sufficient or copious enough as to be able to express our faith without great improprieties, which could lead easily to serious errors" (20).

The Mexican ecclesiastical council in 1555 forbade the creation of an Indian priesthood which meant that the Tlatelolco school lost one of its principal reasons for existence - and the seminary withered away. The consequences of the policy and practice that permitted Tlatelolco to fail and that made difficult if not impossible the entrance of Indians into the clergy were grave for Mexico and for the Church. As Robert Ricard, whose book on The Spiritual Conquest of Mexico is one of the best brief treatments we have of the early ecclesiastical history of Mexico, explains, the Church came to be considered a largely foreign institution whose fortunes were dependent upon the favor of the governing power at the capital, the ruling white Spanish group.

(20). - Hanke, All Mankind is One, p. 26. 
Indians began to enter the priesthood in the seventeenth century, it is true, but in a sporadic fashion, and they were relegated to humble positions in rural parishes. There came into being, says Ricard, two groups of clergy who knew very little of each other, who loved each other hardly a tall, and whose mutual antagonism may be symbolized by the rivalry between the two Virgins: that of the Indians, the Virgen de Guadalupe, and that of the Spaniards, the Virgen de los Remedios, the Gachupina. The Indians were served by a poor and miserable clergy, but the Spaniards had a white clergy that belonged to the ruling class and enjoyed enormous revenues. Ricard concludes that

\footnotetext{
"if the colegio at Tlatelolco had trained only one bishop for the country, the whole history of the Mexican Church would have been far different".
}

The controversy over the nature of the Indians and also the related question of whether force should be used in their conversion to the Christian faith came to a head - at least so far as Las Casas is concerned - in 1550 at Valladolid, where he attacked the ideas of an outstanding Spanish scholar, Juan Ginés de Sepúlveda, who held that Indians were definitely inferior to Spaniards, and that force was necessary to make them Christians. The Emperor Charles $\mathrm{V}$ and his advisors were sufficiently impressed by the problems created by this dispute to order conquests in the New World stopped until it could be determined whether they were just, and to set up in Valladolid a Council of theologians and jurists to listen to the arguments of Las Casas and Sepúlveda.

We know a great deal about this dispute, thanks to the treatises written by the contestants. In the Las Casas work, recently published by Northern Illinois University Press, we find his detailed arguments against Sepúlveda expressed with a singular force and richness. This treatise, translated into English from the Latin manuscript in the Bibliothèque Nationale in Paris by Dr. Stafford Poole, C. M., is entitled: Defense Against the Persecutors and Slanderers of the Peoples of the New World Discovered Across the Sea (21). In this polemical volume, Las Casas sets forth in tremendous detail his passionate conviction that "all the peoples of the world are men" and consequently can become Christians - if only they are properly educated by peaceful means in the true faith (22). This remarkable doctrine was the first enuncia-

(21). - Northern Illinois University Press, 1974.

(22). - For an analysis of the treatise and a historical background on the question of the capacity of the Indians, see Hanke, All Mankind is One. 
tion in the modern world that all mankind is one, that all may be saved - a fundamental doctrine of "open admission" to the celestial world. When the full story of the theological significance of the discovery of America is known, surely this Defense will be recognized as one the fundamental documents in the history of those great disputes which shook the Iberian world in the sixteenthe century.

LEWIS ULYSSES HANKE. American historian. $B .1905$. Educ. Northwestern Univ. (BS) and Harvard Univ. (PhD). $M$. 1926, Kate Ogden Gilbert. S. Jonathan and Peter, Daus. Susan and Joanne. Career: Instructor, Univ. of Hawaii 1926-27; Adjunct Prof., American Univ. of Beirut 1927-30; Tutor, Harvard Univ. 1934-39; Director, Hispanic Foundation, Library of Congress 1939-51; Professor of Latin American History 1951-61, and Director, Institute of Latin American Studies 1951-58, Univ. of Texas; Professor of History, Columbia Univ. 1961-67; Univ. of California, Irvine, 1967-69. Professor of Latin American History, Univ. of Massachusetts. 1969-; member, Board of Trustees, Hispanic Society of America, Apr. 1961-. Publications: First Social Experiments in America, (1935); Spanish Struggle for Justice in the Conquest of America, (1949); Aristotle and the American Indians, (1959); Modern Latin America - Continent in Ferment (2 vols. 1966); History of Latin American Civilization (2 vols. 1967). Editor: Handbook of Latin American Studies, 1937-40; Hispanic American Historical Review, 1954-60, (with Manuel Giménez Fernández), Bartolomé de las Casas - Bibliografia Critica; Historia de la Villa Imperial de Potosí (3 vols.) (with Gunnar Mendoza 1965); Orden del Sol (Peru); Cruzeiro do Sul (Brazil); Condor de los Andes (Bolivia). Beveridge Prize, American Historical Association 1947; Doctor Honoris Causa, Universidade da Bahia 1959; Univ. Tomás Friás 1965, and Univ. de Sevilla 1966. Texas Institute of Letters Prize 1960. Member: America Historical Assocn.; Corresponding Member: historical academies of Argentina, Cuba, Spain, Guatemala, Venezuela. Clubs: Cosmos (Washington); Beta Theta Pi. Address: Dept. of History, Univ. of Massachusetts, Amherst, Mass., 01002, U.S.A. 1974. President, American Historical Association January, 1975. Retired as Professor Emeritus, University of Massachusetts. 